\title{
Flavonoid Accumulation in Cell Suspension Cultures of Glycyrrhiza inflata Batal under Optimizing Conditions
}

\author{
Ying Yang*, Feng He, Longjiang Yu*, Jiaxing Ji, and Yezhen Wang \\ College of Life Science and Technology, Huazhong University of Science and Technology, \\ Wuhan 430074, China. Fax: +86-27-87 7922 65. E-mail: Yulj@hust.edu.cn \\ * Authors for correspondence and reprint requests \\ Z. Naturforsch. 64c, 68-72 (2009); received June 20/August 4, 2008 \\ Cell growth and flavonoid production in cell suspension cultures of Glycyrrhiza inflata \\ Batal were investigated under various initial inoculum densities, and sucrose and nitrogen \\ concentrations to develop an optimization method for an improved flavonoid production. \\ Both biomass accumulation and flavonoid production exhibited an "S" curve in one cul- \\ ture cycle, with the greatest value obtained on day 21, which showed that cell growth and \\ flavonoid biosynthesis went along isochronously. Moreover, according to the biomass and \\ flavonoid production, the appreciate inoculum density, and the sucrose and nitrogen concen- \\ trations were $50 \mathrm{~g} \mathrm{FW} \mathrm{L}^{-1}, 50 \mathrm{~g} \mathrm{~L}^{-1}$ and $120 \mathrm{mmol} \mathrm{L}^{-1}$, respectively. In addition, cell growth \\ and flavonoid production showed a peak of $16.4 \mathrm{~g} \mathrm{DW} \mathrm{L}^{-1}$ and $95.7 \mathrm{mg} \mathrm{L}^{-1}$ on day 21 under \\ the optimizing conditions, respectively. The flavonoid productivity of the cells which were \\ cultured for 3 years is higher than that of the 3-year-old plant, which suggested that fla- \\ vonoid production by cell cultures of $G$. inflata is a potentially profitable method. Therefore, \\ this work is considered to be helpful for efficient large-scale bioprocessing of cell cultures \\ in bioreactors.
}

Key words: Flavonoid Production, Glycyrrhiza inflata Batal, Optimizing Conditions

\section{Introduction}

Licorice has extensively been used as a traditional Chinese medicine for over 2000 years. It not only has anti-inflammatory, antibacterial and antiviral activities, but also has immunomodulating, antioxidant and free radical scavenging activities (Shetty et al., 2002). Glycyrrhiza inflata Batal, an important specie of licorice, has been frequently used to treat phthisis, contagious hepatitis, ague and gastric diseases (Wang et al., 2004). Through pharmacological studies and clinical practice flavonoids have been demonstrated to carry significant biological or antioxidation activities (Li et al., 1998; Fukai et al., 2002). Usually, it takes at least three years for $G$. inflata plants to be harvested for medicinal purposes. A plant cell culture, a useful method for the production of valuable secondary metabolites, provides an attractive alternative source that can overcome the limitations of extracting useful metabolites from limited natural resources (Thanh et al., 2006; Smolenskaya et al., 2007). It is now widely used as a model system to investigate the production of specific secondary metabolites, because it offers experimental advantages both to basic and applied research and to the development of models with scale-up potential (Buitelaar and Trapmer, 1992).

There were very few studies on cell suspension cultures of $G$. inflata which primarily focused on the study of separation, purification and pharmacology of the flavonoids (Asada et al., 1998; Li et al., 1998, 2000). Moreover, the regulation of the flavonoid biosynthesis in cell suspension cultures of $G$. inflata has not yet been systematically investigated. In plant cell cultures, carbon sources, nitrogen sources, phosphate sources, conditioned medium, inoculum density, and $\mathrm{CO}_{2}$ accumulation are known to be the main limiting factors. Carbohydrates, especially sucrose, are important carbon and energy sources for most plant cell lines. It has been demonstrated that the initial sucrose concentration can affect a number of culture parameters of secondary metabolites in plant cell cultures such as growth rate and yield (Benavides, 1997; Zhong and Yoshida,1995; Wang et al.,1997). Consequently, some culture conditions, such as inoculum density, sucrose and nitrogen concentration in the medium, were individually investigated in the present study to develop an optimization method for improved flavonoid production, to ultimately establish a stable cell suspension culture of $G$. inflata. 


\section{Materials and Methods}

\section{Plant material and culture conditions for callus induction}

The calli were derived from the seeds of $G$. inflata Batal, which were obtained from wild plants growing in the desert of Xinjiang in China, donated by an incorporated company of Xinjiang Kunlunshennong of Northwestern China, and identified by the Planting Center of Glycyrrhiza of Xinjiang, China. Seeds were set in a beaker and $98 \%$ $\mathrm{H}_{2} \mathrm{SO}_{4}$ was added to facilitate germination. Then the seeds were cleaned under running tap water and surface-sterilized by $75 \%$ ethanol for several minutes. This was followed by two treatments of 10 min rinse in $0.1 \%$ mercuric chloride solution and washing with sterile distilled water for five times. After surface-sterilization, the seeds were placed separately in $30 \mathrm{~mL}$ Murashige and Skoog (MS) basal medium in 100-mL flasks, and kept in the dark before germination. The cotyledons and hypocotyls were excised when they grew to a length of 3-4 cm, and placed on the surface of MS medium containing 3\% sucrose and $0.8 \%$ agar supplemented with 2,4-dichlorophenoxyacetic acid (2,4-D, $\left.1.0 \mathrm{mg} \mathrm{L}^{-1}\right)$, naphthalene acetic acid (NAA, $1.0 \mathrm{mg} \mathrm{L}^{-1}$ ), and 6-benzyladenine (6-BA, $\left.1.0 \mathrm{mg} \mathrm{L}^{-1}\right)$. All the cultures were maintained at $(25 \pm 1){ }^{\circ} \mathrm{C}$ under $16 \mathrm{~h}$ illumination with $60 \mu \mathrm{mol}$ $\mathrm{m}^{-2} \mathrm{~s}^{-1}$.

\section{Suspension culture establishment and cell growth determination}

The suspension cells were derived from the calli tissue; $5 \mathrm{~g}$ calli in a $250-\mathrm{mL}$ flask were subcultured with $80 \mathrm{~mL}$ of liquid MS culture medium containing 2,4-D $\left(0.5 \mathrm{mg} \mathrm{L}^{-1}\right)$, NAA $\left(0.5 \mathrm{mg} \mathrm{L}^{-1}\right)$, and 6-BA $\left(0.5 \mathrm{mg} \mathrm{L}^{-1}\right)$ every week until the cells showed continuous and stable accumulation of biomass. Cells of G. inflata were cultured in a 250$\mathrm{mL}$ flask with $80 \mathrm{~mL}$ of modified liquid MS culture medium at $(25 \pm 1){ }^{\circ} \mathrm{C}$ on a rotatory shaker with a speed of 120 rotations per minute (rpm) under $16 \mathrm{~h}$ illumination with $60 \mu \mathrm{mol} \mathrm{m} \mathrm{m}^{-1}$. The medium was autoclaved at $121^{\circ} \mathrm{C}$ for $20 \mathrm{~min}$.

After cultured in one cycle, the cells were harvested by filtration via a Buchner funnel, washed with distilled water to remove residual medium, and filtered again. Then the weighed fresh cells (FW) were dried at $50{ }^{\circ} \mathrm{C}$ to constant dry weight (DW). Cell growth was measured based on the DW.
Assay of flavonoids

The dried pulverized cell samples were weighed ( $0.10 \mathrm{~g}$ exactly) and put into a $10-\mathrm{mL}$ measuring flask. The flavonoids were extracted with $3 \mathrm{~mL}$ ethanol/water $(70: 30, \mathrm{v} / \mathrm{v})$ by ultrasonication for $1 \mathrm{~h}$ at $25^{\circ} \mathrm{C}$. After centrifugation at $5500 \times g$ for $6 \mathrm{~min}$, the supernatant was extracted three times with EtOAc, then with $95 \%$ ethanol. The flavonoid content was the combination of the mass of flavonoids in cells and medium, and was determined by colourimetry according to Zhang et al. (2001). Rutin was used as the standard sample.

\section{Statistical analysis}

All data are represented as means \pm standard errors (SE). Every experiment was repeated at least 3 times. The significant difference between the treatment and the control was statistically evaluated by analysis of variance (ANOVA).

\section{Results and Discussion}

\section{Time course of cell growth and flavonoid accumulation}

The cell suspension cultures showed continuous and stable accumulation of biomass after 10 subcultures. According to Fig. 1, the time courses of biomass accumulation describe an "S" growth

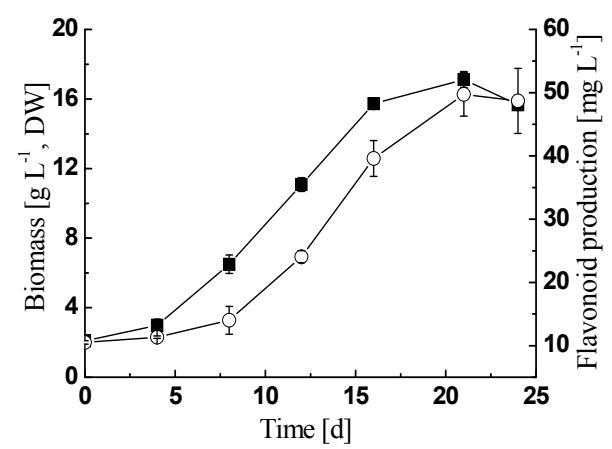

Fig. 1. Time courses of cell growth and flavonoid production in cell suspension cultures of $G$. inflata. The suspension cultures were grown in liquid MS medium containing $0.5 \mathrm{mg} \mathrm{L}^{-1} 2,4-\mathrm{D}, 0.5 \mathrm{mg} \mathrm{L}^{-1} \mathrm{NAA}$, and $0.5 \mathrm{mg} \mathrm{L}^{-1}$ 6-BA. and $\circ$ represent biomass and flavonoid production, respectively. Each data indicates the mean of three independent experiments (mean $\pm \mathrm{SE}$ ). 
curve in one culture cycle. Cells grew very slowly during the initial $4 \mathrm{~d}$ of cultivation. Thereafter, biomass accumulated rapidly, and reached the greatest value of $17.1 \mathrm{~g} \mathrm{~L}^{-1}$ on day 21 . Then the culture entered the stationary phase. Some cultures continued to grow up to day 30 , but invariably darkened and appeared less healthy. The flavonoid production increased significantly from the sixth day and reached a peak of $49.7 \mathrm{mg} \mathrm{L}^{-1}$ on day 21 , then it began to decrease. The results mentioned above indicate that cell growth and flavonoid synthesis went along isochronously in a favourable culture cycle of 21 days.

\section{Effects of inoculum density on cell growth and flavonoid production of cell suspension cultures of $G$. inflata}

The inoculum density is an important factor for plant cell cultures, which can influence not only the cell growth, but also the accumulation of secondary metabolites. Therefore, fresh G. inflata cells from 5 to $80 \mathrm{~g} \mathrm{~L}^{-1}$ were transferred into 250 -mL flasks. As showed in Fig. 2, the biomass and flavonoid production were low at a low inoculum density of $5 \mathrm{~g}$ $\mathrm{FW} \mathrm{L}{ }^{-1}$, while they both increased with increasing

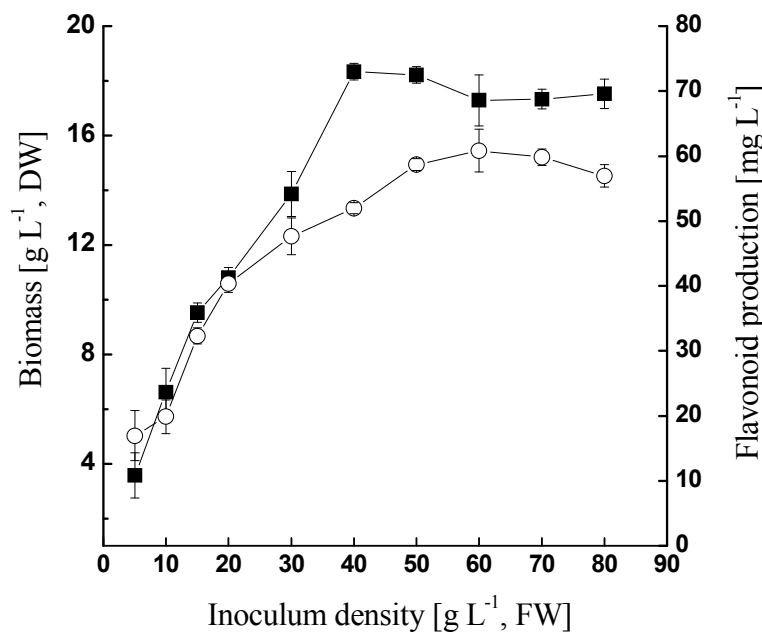

Fig. 2. Biomass and flavonoid accumulation in cell suspension cultures of $G$. inflata inoculated at different inoculum densities. The suspension cultures were grown in MS liquid medium containing $0.5 \mathrm{mg} \mathrm{L}^{-1} 2,4-\mathrm{D}, 0.5 \mathrm{mg}$ $\mathrm{L}^{-1} \mathrm{NAA}$, and $0.5 \mathrm{mg} \mathrm{L}^{-1} 6-\mathrm{BA}$. a and $\circ$ represent biomass and flavonoid production, respectively. Each data indicates the mean of three independent experiments $($ mean $\pm \mathrm{SE})$. inoculum density, and reached the peak of $18.2 \mathrm{~g}$ DW $\mathrm{L}^{-1}$ and $58.7 \mathrm{mg} \mathrm{L}^{-1}$ at an inoculum density of $50 \mathrm{~g} \mathrm{FW} \mathrm{L}^{-1}$, respectively. Further increases in the inoculum density produced a decline in the flavonoid accumulation. These results were found in many plant cell cultures (Wang et al., 1997). A maximum cell biomass of Perilla frutescens was obtained at an elevated inoculum density of $50 \mathrm{~g}$ $\mathrm{FW} \mathrm{L}^{-1}$, and the anthocyanin production was enhanced 23-fold (Zhong and Yoshida, 1995). These results suggested that a higher final cell biomass may be achieved in a cell culture with a higher inoculum density. The mechanisms may include medium composition and culture conditions (Schlatmann et al., 1994). Furthermore, disparity in cell inoculum density could lead to a large difference in culture parameters, for example the concentrations of dissolved oxygen and dissolved gaseous metabolites as well as the related enzyme activities could be altered by accumulated cell biomass. Directly or indirectly, these changes could further affect the cell metabolism. Additionally, it is also possible that initial cell-to-cell communication and/or unknown factors released by inoculum cells are playing a significant role in cell cultures.

Effects of sucrose or nitrogen concentration on cell growth and flavonoid production of cell suspension cultures of G. inflata

Nutrition is required to keep cells growing. As a carbon source, sucrose is used to not only provide the carbon framework of cell essential structural components, but also to offer the energy re-

Table I. The biomass and flavonoid production of cell suspension cultures of $G$. inflata under different sucrose or nitrogen concentrations. The suspension cultures were grown in MS liquid medium containing $0.5 \mathrm{mg} \mathrm{L}^{-1}$ 2,4-D, $0.5 \mathrm{mg} \mathrm{L}^{-1} \mathrm{NAA}$, and $0.5 \mathrm{mg} \mathrm{L}^{-1} 6-\mathrm{BA}$. Each data indicates the mean of three independent experiments $($ mean $\pm \mathrm{SE})$.

\begin{tabular}{lcl}
\hline Concentration of & Biomass $\left[\mathrm{g} \mathrm{L}^{-1}\right]$ & $\begin{array}{l}\text { Flavonoid } \\
\text { production }\left[\mathrm{mg} \mathrm{L}^{-1}\right]\end{array}$ \\
\hline Sucrose $\left[\mathrm{g} \mathrm{L}^{-1}\right]$ & $4.9 \pm 0.49$ & $18.8 \pm 1.06$ \\
10 & $15.6 \pm 0.24$ & $72.3 \pm 3.78$ \\
50 & $9.4 \pm 0.62$ & $36.4 \pm 1.91$ \\
Nitrogen $\left[\mathrm{mmol} \mathrm{L}^{-1}\right]$ & \\
10 & $13.1 \pm 0.56$ & $73.1 \pm 2.20$ \\
120 &
\end{tabular}

Nitrogen consists of ammonia and nitrate in a ration of $1: 1.8$. 
quired for growth and maintenance. The nitrogen source plays an important role in the synthesis of nucleic acids and proteins. The effects of initial sucrose or nitrogen concentration on growth and flavonoid production of cell suspension cultures of G. inflata are shown in Table I. Both the biomass and flavonoid production increased with increasing sucrose or nitrogen concentration, and reached the peak of $15.6 \mathrm{~g} \mathrm{~L}^{-1}$ and $72.3 \mathrm{mg} \mathrm{L}^{-1}$ with the sucrose concentration of $50 \mathrm{~g} \mathrm{~L}^{-1}$, and of $13.1 \mathrm{~g}$ $\mathrm{L}^{-1}$ and $73.1 \mathrm{mg} \mathrm{L}^{-1}$ with the nitrogen concentration of $120 \mathrm{mmol} \mathrm{L}^{-1}$, respectively. In suspension cultures of Perilla frutescens for the production of anthocyanin pigments, a relatively high sucrose concentration $\left(45 \mathrm{~g} \mathrm{~L}^{-1}\right)$ was reported to be favourable for pigment accumulation (Zhong and Yoshida, 1995). Sucrose regarded as a regulator of osmotic pressure, might take an important role concerning the osmotic pressure in the medium. The positive effects of osmotic potential, provoked by high sucrose concentrations in the medium, on the accumulation of anthocyanins have been demonstrated in cell cultures of Daucus carota (Rajendran et al., 1992). Thus, it can be speculated that a certain level of osmotic stress caused by a relatively higher initial sucrose concentration may be favourable to product formation, but represses the cell growth.

\section{Cell growth and flavonoid accumulation under the optimizing conditions}

The cells were cultured with the sucrose and nitrogen concentration of $50 \mathrm{~g} \mathrm{~L}^{-1}$ and $120 \mathrm{mmol}$ $\mathrm{L}^{-1}$, at an inoculum density of $50 \mathrm{~g} \mathrm{FW} \mathrm{L} \mathrm{L}^{-1}$, respectively. The time courses of biomass accumulation and flavonoid production are shown in Fig. 3. From the sixth day, biomass accumulated rapidly and reached the greatest values of $16.4 \mathrm{~g} \mathrm{~L}^{-1}$ on day 21. Flavonoid production also reached a peak

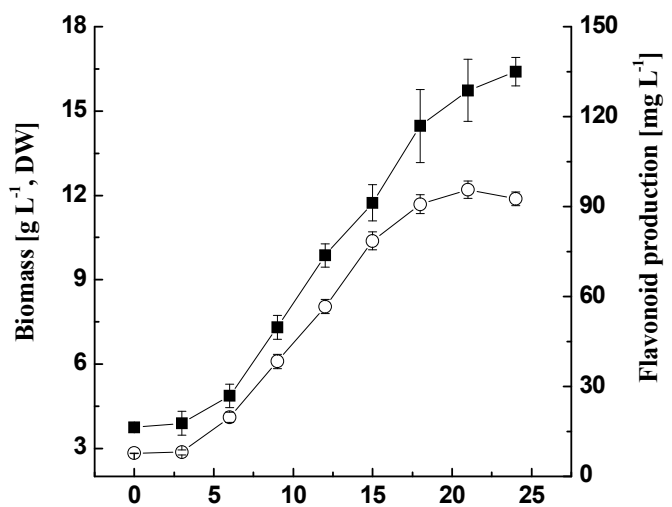

Fig. 3. Cell growth and flavonoid production in cell suspension cultures of $G$. inflata in the optimizing MS medium with sucrose and nitrogen concentrations of $50 \mathrm{~g}$ $\mathrm{L}^{-1}$ and $120 \mathrm{mmol} \mathrm{L}^{-1}$, respectively, and an inoculum density of $50 \mathrm{~g} \mathrm{FW} \mathrm{L}^{-1}$. a and $\circ$ represent biomass and flavonoid production, respectively. Each data indicates the mean of three independent experiments (mean \pm $\mathrm{SE})$.

of $95.7 \mathrm{mg} \mathrm{L}^{-1}$ on day 21, which was 1.93 times of the flavonoid production under the initial conditions. The highest content of flavonoids in one cell culture cycle under the optimizing conditions was only $0.6 \%$ (about $6 \mathrm{mg} \mathrm{g}^{-1} \mathrm{DW}$ ), which was lower than that of a 3-year-old plant in which the flavonoid content always maintained about $3 \%$. However, it takes at least three years for the $G$. inflata plant to be harvested for medicinal purposes, while the cell growth cycle is only 21 days. Thus, the flavonoid productivity of the cells cultured for 3 years is much more than that of the 3 -year-old plant, which suggests that flavonoid production by cell cultures of $G$. inflata is a potentially profitable method. Therefore, this work is considered to be helpful for efficient large-scale bioprocessing of cell cultures in bioreactors. 
Asada Y., Li W., and Yoshikawa T. (1998), Isoprenylated flavonoids from hairy root cultures of Glycyrrhiza glabra. Phytochemistry 47, 389-392.

Benavides M. P. (1997), Growth and thiophene accumulation are influenced by sucrose, light and subculture in cell suspensions and root cultures of Tagetes argentina. Biocell 21, 1-11.

Buitelaar R. M. and Trapmer J. (1992), Strategies to improve the production of secondary metabolites with plant cell cultures: a literature review. J. Biotechnol. 23, $111-141$.

Fukai T., Marumo A., Kaitou K., Kanda T., Terada S., and Nomura T. (2002), Antimicrobial activity of licorice flavonoids against methicillin-resistant Staphylococcus aureus. Fitoterapia 73, 536-539.

Li W., Asada Y., and Yoshikawa T. (1998), Antimicrobial flavonoids from Glycyrrhiza glabra hairy root cultures. Planta Med. 64, 746-747.

Li W., Asada Y., and Yoshikawa T. (2000), Flavonoid constituents from Glycyrrhiza glabra hairy root cultures. Phytochemistry 55, 447-456.

Rajendran L., Ravishankar G. A., Venkataraman L. V., and Prathiba K. R. (1992), Anthocyanin production in callus cultures of Daucus carota influenced by nutrient stress and osmoticum. Biotechnol. Lett. 14, $707-712$.

Schlatmann J. E., Moreno P. R. H., Vinke J. L., ten Hoopen H. J. G., Verpoorte R., and Heijnen J. J. (1994), Effect of oxygen and nutrient limitation on ajmalicine production and related enzyme activities in high density cultures of Catharanthus roseus. Biotechnol. Bioeng. 44, 461-468.
Shetty T. K., Satav J. G., and Nair C. K. K. (2002), Protection of DNA and microsomal membranes in vitro by Glycyrrhiza glabra L. against gamma irradiation. Phytother. Res. 16, 576-578.

Smolenskaya I. N., Reshetnyak O. V., Nosov A. V., Zoriniants S. E., Chaiko A. L., Smirnova Y. N., and Nosov A. M. (2007), Ginsenoside production, growth and cytogenetic characteristics of sustained Panax japonicus var. repens cell suspension culture. Biol. Plant. 51, 235-241.

Thanh N. T., Murthy H. N., Pandey D. M., Yu K. W., Hahn E. J., and Paek K. Y. (2006), Effect of carbon dioxide on cell growth and saponin production in suspension cultures of Panax ginseng. Biol. Plant. 50, $752-754$.

Wang H. Q., Zhong J. J., and Yu J. T. (1997), Enhanced production of taxol in suspension cultures of Taxus chinesis by controlling inoculum size. Biotechnol. Lett. 19, 353-355.

Wang Q. E., Lee F. S. C., and Wang X. R. (2004), Isolation and purification of inflacoumarin $\mathrm{A}$ and licochalcone A from licorice by high-speed counter-current chromatography. J. Chromatogr. A 1048, 51-57.

Zhang X. H., Zhao Y. F., and Chen J. M. (2001), Determination of flavonoids content of Glycyrrhiza. China J. Chin. Materia Media 26, 746-747.

Zhong J. J. and Yoshida T. (1995), High-density cultivation of Perilla frutescens cell suspensions for anthocyanin production: effects of sucrose concentration and inoculum size. Enzym. Microb. Technol. 17, 1073-1079. 